\title{
Capsule Commentary: Mehta et al. Electronic Pill Bottles or Bidirectional Text Messaging to Improve Hypertension Medication Adherence
}

\author{
Paul Sorum, MD, PhD \\ Departments of Internal Medicine and Pediatrics, Albany Medical College, Albany, NY, USA.
}

$\mathrm{J}$ Gen Intern Med 34(11):2584

DOI: $10.1007 / \mathrm{s} 11606-019-05280-4$

(c) Society of General Internal Medicine 2019

$\mathrm{M}$ ehta and colleagues ${ }^{1}$ performed a randomized controlled trial of the impact on inadequately controlled blood pressures of two technological interventions to improve medication adherence. ${ }^{2-4}$ They compared usual care to electronic pill bottles that notified the study's electronic platform when the patients opened them and to bidirectional text messaging from the platform that asked the patients to text back if they took the medication. The patients of both intervention groups received messages each day reporting on the previous day and reminding them to take their medications. Neither intervention lowered systolic blood pressures at 4 months more than did usual care.

Why the lack of impact? The authors provide four possible answers. First, the problem may not have been adherence, but lack of appropriate dose escalation. Second, the improvements in adherence, if they occurred, may not have been enough to show improvement. Third, the patient population, mostly African-Americans in clinics with a considerable focus already on blood pressure control, may have had particularly resistant hypertension. Fourth, the effect may have been masked by the improvement in the control group, as a result of regression to the mean, of participating in a study, with its financial incentives to participate and return for followup, or of taking their medications merely for the followup visit.

The additional possibility is that these technological interventions do not work very well. Indeed, there was no difference between arms in self-reported adherence at the end of the study. In addition, the measured adherences of $70.8 \%$ with electronic pill bottles and $77.0 \%$ with bidirectional texting were the rates only of opening the bottle or sending a text response, not actually of taking the

Published online August 19, 2019 pill. Furthermore, Mehta and colleagues are not alone in achieving apparent improvements in adherence but not in clinical outcomes. ${ }^{2,5}$

What to do? While the participants' high recommendations of both technologies (9 out of 10) should encourage us not to abandon technology, the answer to improving blood pressure control is likely to be more intensive interactions between patients and clinicians.

Corresponding Author: Paul Sorum, MD, PhD; Departments of Internal Medicine and Pediatrics, Albany Medical College, Albany, NY, USA (e-mail: sorump@amc.edu).

\section{Compliance with Ethical Standards:}

Conflict of Interest: The author declares that he does not have a conflict of interest.

Publisher's Note: Springer Nature remains neutral with regard to jurisdictional claims in published maps and institutional affiliations.

\section{REFERENCES}

1. Mehta SJ, Volpp KG, Troxel AB, Day SC, Lim R, Marcus N, Norton L, Anderson S, Asch DA. Electronic pill bottles or bidirectional text messaging to improve hypertension medication adherence (Way 2 Text): A randomized clinical trial. J Gen Intern Med 2019 https://doi.org/10. 1007/11606.1525-1497

2. van Onzenoort HA, Verberk WJ, Kessels AG, Kroon AA, Neef C, van der Kuy PH, de Leeuw PW. Assessing medication adherence simultaneously by electronic monitoring and pill count in patients with mild-to-moderate hypertension. Am J Hypertens 2010;23(2):149-54.

3. Thakkar J, Kurup R, Laba T-LO, Santo K, Thiagalingam A, Rodgers A, Woodward M, Redfern J, Chow CK. Mobile telephone text messaging for medication adherence in chronic disease: a meta-analysis. JAMA Intern Med 2016;176(3):340-9.

4. Kessler JB, Troxel AB, Asch DA, Mehta SJ, Marcus N, Um R, Zhu J, Shrank W, Brennan T, Volpp KG. Partners and alerts in medication adherence: a randomized clinical trial. J Gen Intern Med 2018;33(9): 1536-42.

5. van Heuckelum M, van den Ende CHM, Houterman AEJ, Hemmskerk

CPM, van Dulmen S, van den Bemt BJF. The effect of electronic monitoring feedback on medication adherence and clinical outcomes: A systematic review. PLOS ONE 2017;12(10): e0185463 https://doi.org/10. 1371/journal.pone.0185453.

Publisher's Note Springer Nature remains neutral with regard to jurisdictional claims in published maps and institutional affiliations. 